УДК 005:656.072

\title{
УДОСКОНАЛЕННЯ АВТОМАТИЗОВАНИХ СИСТЕМ ПАСАЖИРСЬКОГО КОМПЛЕКСУ ПРИ ШВИДКІСНИХ ПЕРЕВЕЗЕННЯХ В УМОВАХ РОЗВИТКУ ІНФОРМАТИЗАЦЇ̈
}

\author{
Канд. техн. наук В. В. Кулешов, слухач Д. М. Чеботарьов \\ УСОВЕРШЕНСТВОВАНИЕ АВТОМАТИЗИРОВАННЫХ СИСТЕМ \\ ПАССАЖИРСКОГО КОМПЛЕКСА ПРИ СКОРОСТНЫХ ПЕРЕВОЗКАХ В \\ УСЛОВИЯХ РАЗВИТИЯ ИНФОРМАТИЗАЦИИ
}

\author{
Канд. техн. наук В. В. Кулешов, Д. Н. Чеботарев

\begin{abstract}
IMPROVING AUTOMATED SYSTEMS THE PASSENGER COMPLEX WITH HIGHSPEED TRANSPORT IN THE CONDITIONS OF INFORMATIZATION DEVELOPMENT
\end{abstract}

\author{
Candidate of Technical Sciences V. Kuleshov, D. Chebotarev
}

Розглянуто перевезення ДП «Украӥнська залізнична швидкісна компанія». Виконано аналіз маршрутної швидкості проходження Південною залізницею пасажирських швидкісних поїздів, корисної довжини колій парків пасажирської станції Харків-Пас. Розглянуто комплекс автоматизованих робочих місиь персоналу пасажирського господарства різних рівнів керування при пасажирських швидкісних перевезеннях. Показано умови оперативного планування роботи пасажирської станції. Наведено схему отримання інформації та планування роботи пасажирського комплексу.

Запропоновано комплекс моделей тривалості відправлення на напрямок, обертання пасажирського швидкісного поїда, потрібної кількості составів пасажирського швидкісного поїза власності УЗШК або іншої операторської пасажирської компанії. Синтез нейроконтролера роботи пасажирської станиії при швидкісних перевезеннях в умовах змінення обсягів перевезень можна виконати на базі тришарової прямонаправленої мережі. Така технологія забезпечує скорочення тривалості перебування вагонів на станції, тобто має ресурсозберігаючу направленість.

Ключові слова: пасажирський вагон, генетичний алгоритм, модель технологї пасажирських швидкісних перевезень, итучні нейронні мережі.

Рассмотрень перевозки ГП «Украинская железнодорожная скоростная компания». Выполнен анализ маршрутной скорости проследования по Южной железной дороге пассажирских скоростных поездов, полезной длины путей парков пассажирской станции Харьков-Пас. Рассмотрен комплекс автоматизированных рабочих мест персонала пассажирского хозяйства разных уровней управления при пассажирских скоростных перевозках. Показаны условия оперативного планирования работы пассажирской станции. Приведена схема получения информации и планирования работы пассажсирского комплекса.

Предложен комплекс моделей продолжительности отправления на направление, обращения пассажирского скоростного поезда, необходимого количества составов пассажирского скоростного поезда собственности УЖСК или другой операторской пассажирской компании. Синтез нейроконтроллера работы пассажирской станции при скоростных перевозках в условиях изменения объемов перевозок возможно выполнить на базе трехслойной прямонаправленной сети. Такая технология обеспечивает сокращение 
продолжительности нахождения вагонов на станции, т. е. имеет ресурсосберегающую направленность.

Ключевые слова: пассажирский вагон, генетический алгоритм, модель технологии пассажирских скоростных перевозок, искусственные нейронные сети.

Discussed transportation of SE «Ukrainian speed railway company». The analysis of the route speed of traversing the southern railway passenger high-speed trains, the effective lengths of the paths of parks passenger station Kharkiv-Pas. The complex of automated working places of the personnel of passenger households of different levels of management in high-speed passenger transport. The conditions of operational planning of passenger station. The scheme of information and planning of work of a passenger complex.

The proposed set of models of duration of administration on the direction, circulation highspeed passenger trains, the required number of passenger trains high-speed trains of ownership USRK operator or other passenger of the company. Synthesis of neurocontroller passenger work station with high speed traffic with changes in traffic may be performed on the basis of the threelayer premenapause network. This technology provides reduction of duration of a finding of cars at the station, i.e. the resource-saving direction.

Keywords: passenger wagon, genetic algorithm, model technology high-speed passenger transport, artificial neural networks.

Вступ. Дотепер програма впровадження швидкісного руху пасажирських поїздів на залізницях України перебуває в стадії поділу пасажирського та вантажного руху. У рамках програми було укладено 5,2 тис. км безстикової колії; проведено реконструкцію інфраструктури напрямків Київ - Харків (532 км), Київ - Дніпро (484 км), Київ - Хутір-Михайлівський (356 км); уведено в експлуатацію 370 безстикових стрілочних переводів 3 безперервною поверхнею кочення; укладено 3,3 тис. км колій на залізобетонних шпалах iз пружними скріпленнями; збільшено швидкість руху пасажирських поїздів до 140 км/год на більш ніж 1,2 тис. км головних колій; досягнуто сумарного техніко-економічного ефекту від впровадження нових технічних рішень, а також ресурсозберігаючих технологій, що перевищує 3 млрд грн. Із загальної експлуатаційної мережі залізниць України (22,05 тис. км) $67,5 \%$ становлять одноколійні ділянки, $32,5 \%$ - дво- i триколійні. Електрифіковано $42,3 \%$ протяжності залізниць, 60,7 \% - обладнано пристроями автоматичного регулювання руху проїздів, $62 \%$ - мають безстикову колію, системами електричної централізації обладнано 72,9 \% усіх стрілок [1].

Відомо, що залізниці Західної Свропи завдяки підвищенню швидкості руху поїздів мають перевагу перед автомобільним транспортом на відстані 250-500 км і конкурують 3 авіаційним у діапазоні 5001000 км. Однак залізничний транспорт України не повною мірою відповідає вимогам щодо тривалості поїздок у пасажирському сполученні. Максимальна швидкість руху пасажирських поїздів 120 км/год (крім напрямків: Київ - Харків та Київ - Дніпропетровськ з максимальною швидкістю руху 140 км/год). Маршрутна швидкість руху пасажирських поїздів на основних напрямках становить 5565 км/год.

Аналіз останніх досліджень i публікацій. У нормативних документах [12] при організації перевезень докладно не враховано застосування методів моделювання роботи пасажирського комплексу при швидкісних перевезеннях в умовах розвитку інформатизації. У попередніх дослідженнях [3 - 12, 14-16] було розглянуто сучасні підходи до удосконалення технології перевезень 
парком вагонів операторських компаній, моделювання пасажирських поїздопотоків високошвидкісних залізниць.

Але потребують розв'язання питання удосконалення технології роботи пасажирського комплексу в умовах розвитку інформатизації при застосуванні методів моделювання технології пасажирських швидкісних перевезень, яка грунтується на основі використання технічних засобів пасажирських комплексів 3 оптимізацією їх основних параметрів.

Визначення мети і задачі дослідження. Мета та задачі дослідження удосконалення автоматизованих систем пасажирського комплексу при пасажирських швидкісних перевезеннях в умовах розвитку інформатизації.

Основна частина дослідження. На сьогоднішній день парк рухомого складу Державного підприємства «Українська залізнична швидкісна компанія» (УЗШК) складається 3 десяти електропоїздів подвійного живлення категорії «Інтерсіті+» виробництва «Hyundai Rotem» і 3 двох електропоїздів подвійного живлення категорії «Інтерсіті» виробництва компанії «Skoda».

Швидкісні електропоїзди «Нyundai» двосистемні поїзди, що працюють на двох видах живлення: на змінному i на постійному струмі. Конфігурація салону, розташування місць, комфорт поїздки в поїздах «Нуundai» відповідає світовій практиці й останнім тенденціям у галузі ергономіки та технічного дизайну.

Загальна кількість місць для сидіння в поїзді - 579. Місця першого класу 168 сидінь, розміщені за схемою $2+2$ один за одним у трьох вагонах по 56 місць кожний. Місця другого класу - 411 сидінь за схемою $3+2$ - розміщені в шести вагонах. Два місця для осіб з обмеженими фізичними можливостями розміщені у головному вагоні. У поїзд включено вагон 3 буфетом і 51 місцем другого класу.
Ширина колії в країнах СНД - 1,52 м, у більшості країн Свропи - 1,435 м. Пасажирські вагони в країнах Європи мають ширину - 2,9 м, в Україні й країнах СНД - 3,5 м, що дало можливість без шкоди комфортності для пасажирів розмістити ще одне пасажирське крісло.

Технічні бази 3 обслуговування рухомого складу УЗШК примикають до станцій Дарниця та Харків-Пас.

У графіку руху на 2013-2014 рр. було заплановано дев'ять маршрутів поїздів УЗШК: із Києва в Харків, Донецьк, Дніпропетровськ, Запоріжжя, Львів та із Дніпропетровська в Сімферополь.

У 2013-2014 рр. 3 причин політичного характеру відмінено швидкісні поїзди категорії «Інтерсіті» по маршрутах: Харків - Донецьк; Донецьк - Дніпропетровськ; Харків, Дніпропетровськ, Донецьк Сімферополь.

Графіком руху на 2015-2016 pp. передбачено 10 швидкісних (до 160 км/год) поїздів категорії «Інтерсіті+» сполученням Києва із містами: Харків, Дніпропетровськ, Запоріжжя, Львів, Одеса, Кривий Ріг, Трускавець, Красноармійськ, Костянтинівка (курсував у Донецьк до 2014 року), Лисичанськ (курсував у Луганськ до 2014 року). Також курсують 17 швидкісних поїздів категорій «Інтерсіті» i «Регіональний експрес» по маршрутах із Києва до міст: Тернопіль, Рівне, Кам'янецьПодільський, Могилів-Подільський, Хмельницький, Шостка, Харків (через Суми), Полтава, Кременчук та інших.

Аналіз прямування коліями Регіональної філії «Південна залізниця» ПАТ «Укрзалізниця» швидкісних електропоїздів відправленням 3 пасажирської станції Харків-Пас. і передаванням на регіональні філії «Південно-Західна» і «Донецька залізниця» ПАТ «Укрзалізниця» 19.05.2016 p. наведено в таблиці. 


\begin{tabular}{|c|c|c|c|c|c|c|c|c|c|}
\hline $\begin{array}{l}\text { 量 } \\
: \frac{m}{0} \\
\frac{0}{8}\end{array}$ & 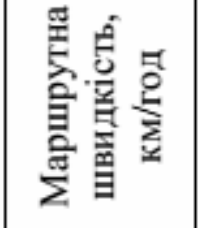 & $\stackrel{\nabla}{\dot{\sigma}}$ & \begin{tabular}{l}
$\infty$ \\
\multirow{0}{0}{}
\end{tabular} & $\hat{0}$ & $\stackrel{n}{\infty}$ & $\stackrel{0}{\infty}$ & $\begin{array}{l}n \\
\dot{\delta}\end{array}$ & $\stackrel{0}{\dot{0}}$ & $\stackrel{m}{8}$ \\
\hline 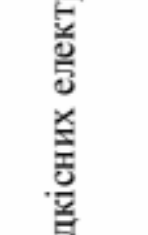 & 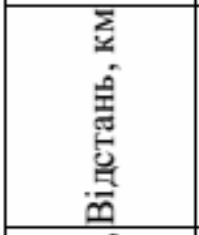 & กี & กิ & న̂ & ని & กี & กิ & $\underset{m}{\stackrel{2}{2}}$ & $\underset{n}{\stackrel{2}{n}}$ \\
\hline 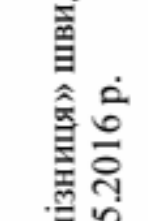 & 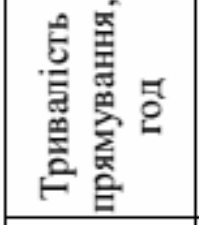 & $\underset{\dot{v}}{\tilde{y}}$ & $\begin{array}{l}\stackrel{2}{2} \\
\text { m. }\end{array}$ & $\begin{array}{c}m \\
m\end{array}$ & $\underset{m}{q}$ & ্ָ & के & $\stackrel{m}{m}$ & $\underset{m}{\stackrel{\infty}{r}}$ \\
\hline 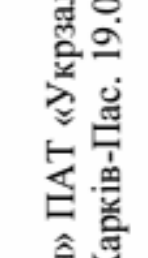 & 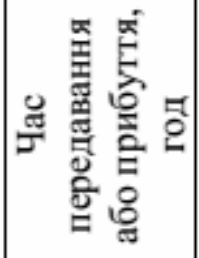 & $\begin{array}{l}\infty \\
\infty \\
\varrho\end{array}$ & $\begin{array}{l}3 \\
6 \\
0\end{array}$ & $\begin{array}{l}\infty \\
= \\
=\end{array}$ & $\begin{array}{l}\tilde{d} \\
\text { di }\end{array}$ & $\frac{\infty}{\infty}$ & $\begin{array}{l}\text { b. } \\
\text { הi }\end{array}$ & $\begin{array}{l}\text { 吕 } \\
=\end{array}$ & $\frac{P}{i}$ \\
\hline 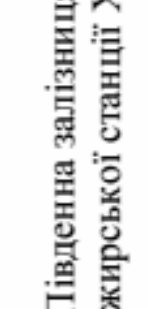 & 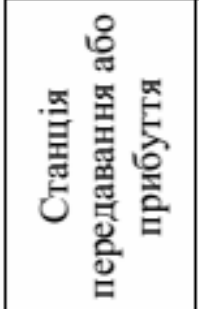 & 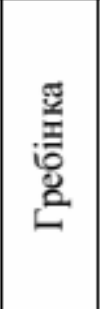 & 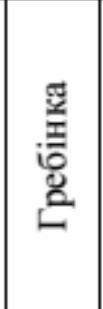 & 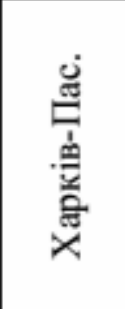 & 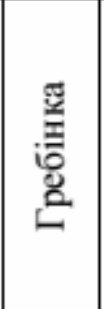 & 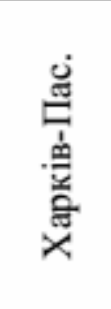 & 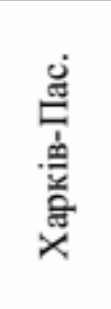 & 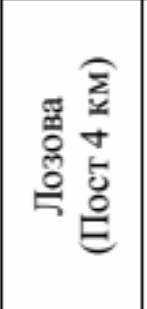 & 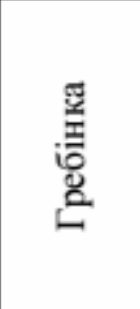 \\
\hline 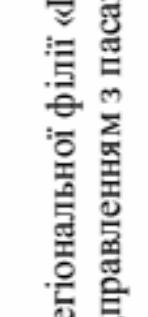 & 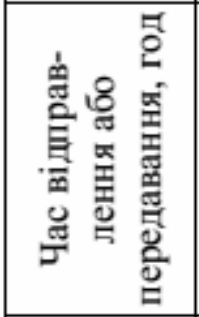 & $\begin{array}{l}\infty \\
\stackrel{m}{r}\end{array}$ & તิ & $\underset{\infty}{\infty}$ & $\begin{array}{l}30 \\
\infty\end{array}$ & 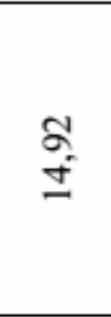 & શે & $\stackrel{n}{6}$ & $\begin{array}{l}\Omega \\
\Sigma\end{array}$ \\
\hline 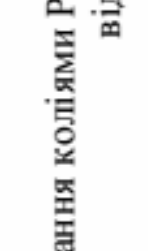 & 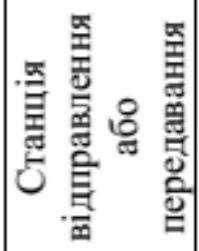 & 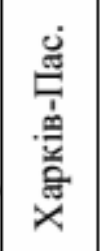 & 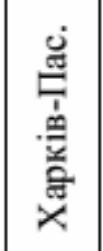 & 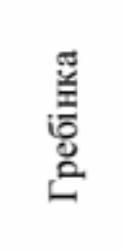 & 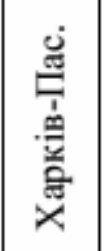 & 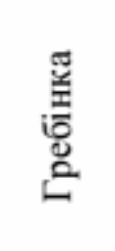 & 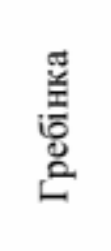 & 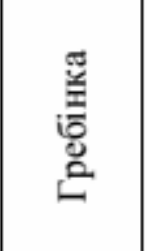 & 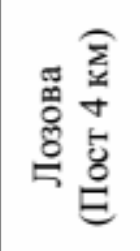 \\
\hline 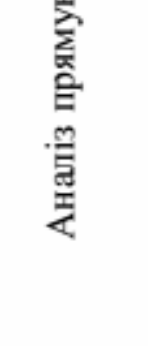 & 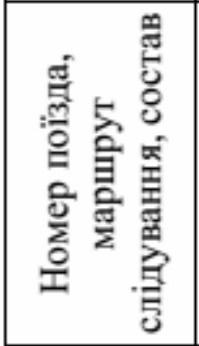 & 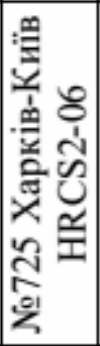 & 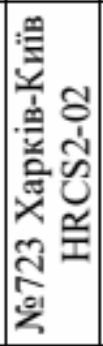 & 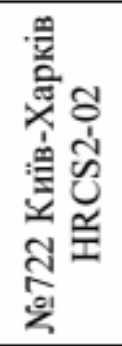 & 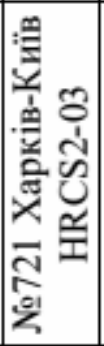 & 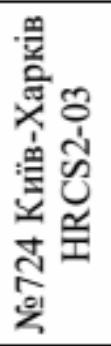 & 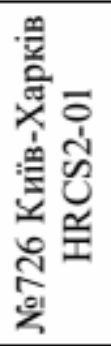 & 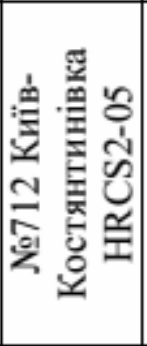 & 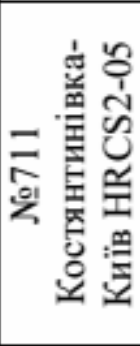 \\
\hline
\end{tabular}


Пасажирський комплекс станції Харків-Пас. складається із семи парків: Приймально-відправного $\quad(17 \quad$ колій корисною довжиною від 214 до 713 м; одна відстійна, корисною довжиною 30 м; одна витяжна, корисною довжиною 94 м), Західного (вісім колій корисною довжиною від 70 до 206 м), Південного (вісім колій корисною довжиною від 116 до 293 м),
Північного (20 колій корисною довжиною від 58 до 544 м), Поштово-багажного (п'ять колій корисною довжиною від 136 до 217 м), Бєлгородського (дві колії корисною довжиною 289 м), парку «Н» (20 колій корисною довжиною від 342 до 1831 м) та Вантажного району (10 колій). Аналіз корисної довжини колій парків станції Харків-Пас. наведенй на рис. 1.

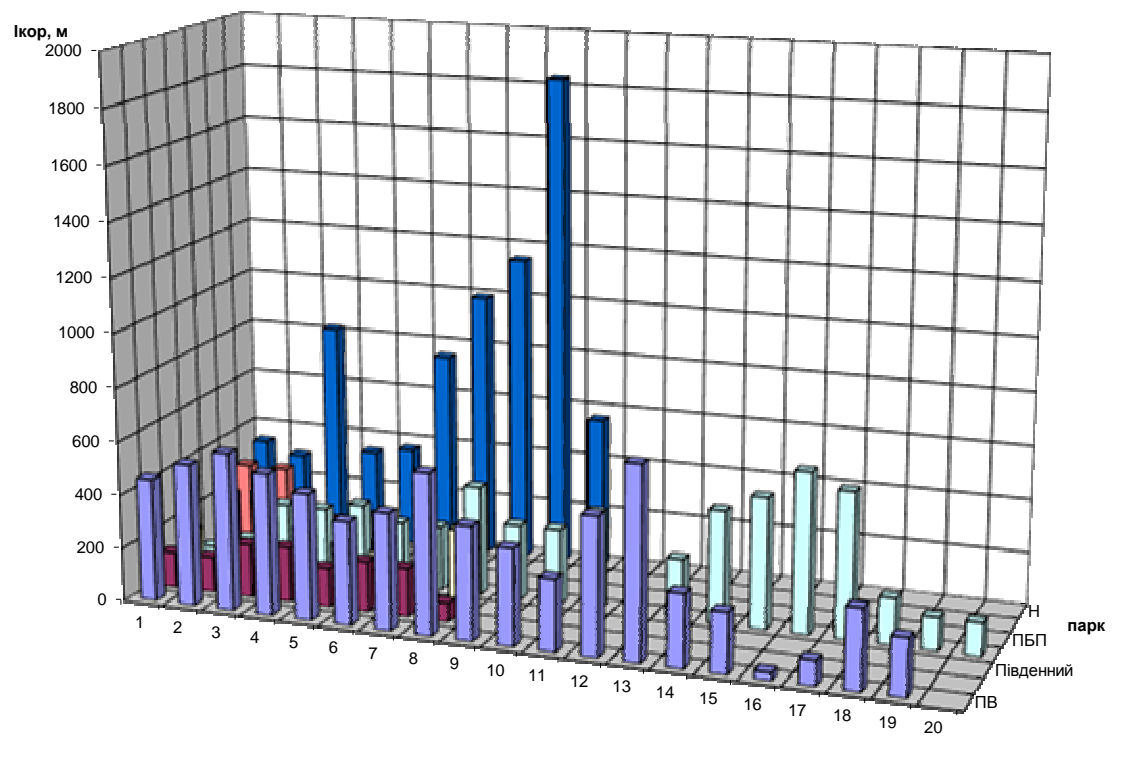

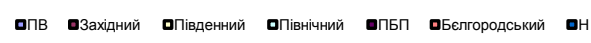

Рис. 1. Аналіз корисної довжини колій парків пасажирської станції Харків-Пас.

Для проведення технологічного i технічного обслуговування швидкісні пасажирські поїзди «Hyundai», «Skoda» за графіком руху вивізних поїздів передаються зі станції Харків-Пас. на Харківську вагонну дільницю поїзним порядком.

У рамках звичайного комплексу автоматизованих робочих місць (АРМ) пасажирського господарства ведеться розклад руху пасажирських та приміських поїздів. Однак проведення логічного контролю повідомлень про рух поїздів виконується через АРМ ДСП Харків-Пас.,
ДНЦ дільниць, працівників служби Д та пасажирського господарства. Вимоги до документування відповідають загальним вимогам до документування АСК ВП УЗ-Є. АРМ для ведення розкладу руху пасажирських поїздів призначено для підтримки розкладу руху в актуальному стані, для проведення логічного контролю повідомлень про рух пасажирських та приміських поїздів. Для коригування розкладу руху передбачено чотири режими (рис. 1): введення нового поїзда, редагування поїзда, вилучення, сервіс (перегляд даних про поїзд) [3]. 


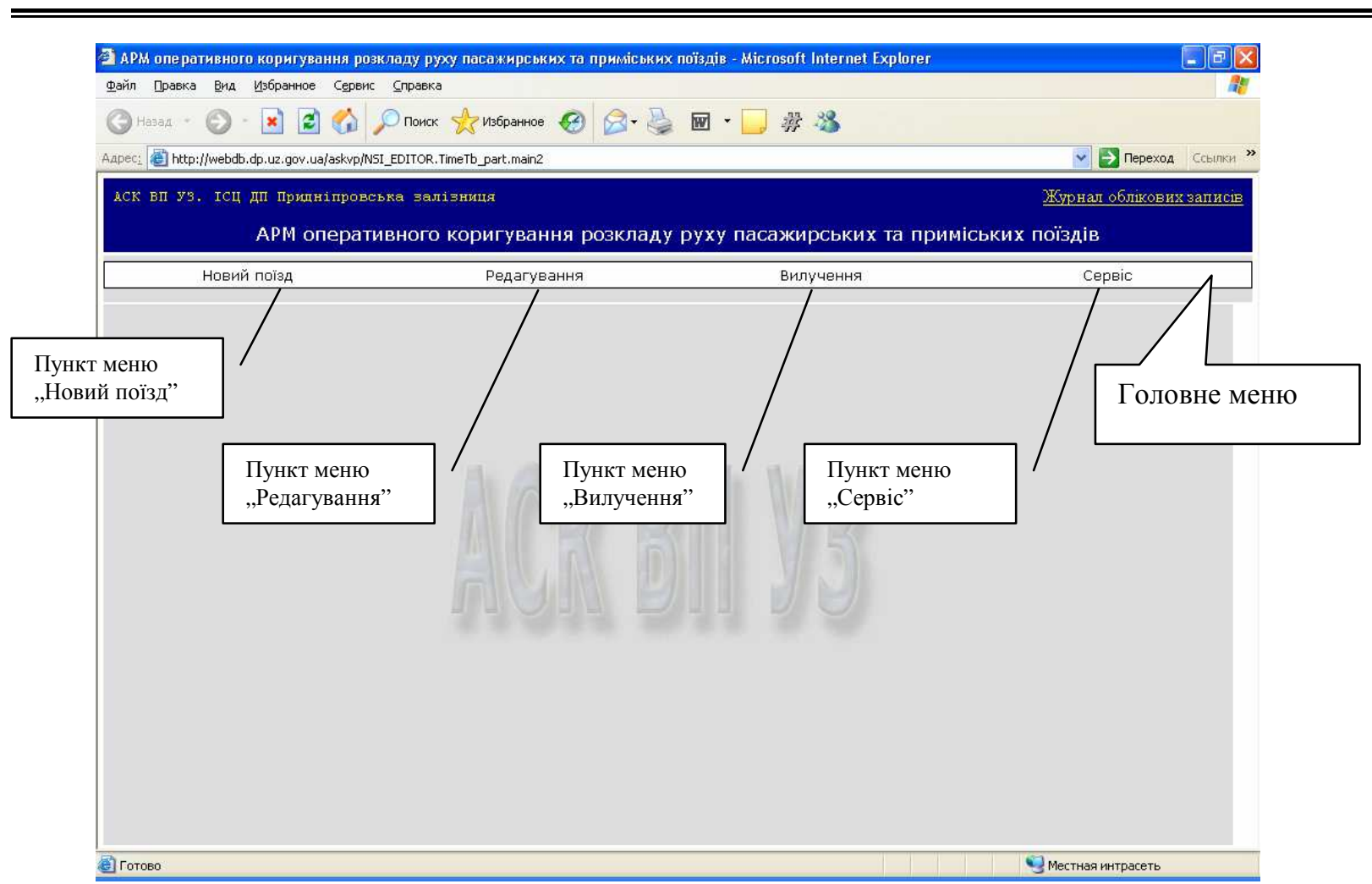

Рис. 1. Головне вікно АРМ ведення розкладу руху пасажирських та приміських поїздів

АСК пасажирського комплексу при швидкісних перевезеннях потребує удосконалення АРM персоналу пасажирських та пасажирських технічних станцій з метою підвищення ефективності оперативної роботи 3 пасажирськими швидкісними поїздами; організації інформаційної підтримки та безперебійного забезпечення оперативними даними про розклад руху пасажирських швидкісних поїздів та матеріального забезпечення пасажирського господарства залізниць, УЗШК та інших операторських компаній; забезпечення оперативного коригування нормативно-довідкової інформації стосовно пасажирських швидкісних поїздів для проведення логічних контролів повідомлень про рух поїздів.

За допомогою АСК пасажирського комплексу при швидкісних перевезеннях для ведення розкладу руху пасажирських швидкісних поїздів можна вирішувати такі задачі:
- оперативне відображення розкладу руху пасажирських швидкісних поїздів по всьому напрямку, починаючи зі станції формування, та інформації про його курсування з урахуванням графіка руху;

- автоматизація коригування інформації про напрямки руху, часу прибуття або відправлення пасажирських швидкісних поїздів;

- автоматизація коригування ознак парності та різниць дат пасажирських швидкісних поїздів;

- автоматизація додавання (видалення) розкладу руху для пасажирських швидкісних поїздів;

- відображення інформації про роботу користувачів АРМ за допомогою перегляду «Журналу облікових записів»;

- відображення розкладу руху пасажирських швидкісних поїздів у різних довідках;

- створення єдиної системи інформаційної підтримки для коректного проведення логічних контролів повідомлень про рух 
пасажирських швидкісних поїздів, що забезпечить надання оперативної інформації на АРМ персоналу, пов'язаного iз введенням повідомлень про рух пасажирських швидкісних поїздів.

Особливістю АСК пасажирського комплексу при швидкісних перевезеннях $\epsilon$ оперативність, введення в АСК ВП УЗ-С інформації про розклад руху, напрямки прямування та курсування пасажирських швидкісних поїздів здійснюється в реальному масштабі часу.

В результаті розробки АCK пасажирського комплексу при швидкісних перевезеннях має бути створено програмний комплекс, що має взаємодіяти iз загальносистемними і функціональними комплексами АСК ВП УЗ-С. Надійність функціонування компонента, його безпека, ергономіка та технічна естетика, експлуатаційні характеристики, захист інформації та эï збереження мають відповідати загальним вимогам АСК ВП УЗ-С.

Створення АСК пасажирського комплексу при швидкісних перевезеннях передбачає такі основні етапи:

- розробка загальної технології та реалізації програмних засобів створення АРМ для ведення розкладу руху пасажирських швидкісних поїздів;

- розробка задачі, включаючи опис постановки задачі, керівництво користувача, програмне забезпечення, програму та методику випробувань;

- комплексне налагодження функцій АРМ на дослідному полігоні АСК ВП УЗ-С.

Вхідною інформацією АСК пасажирського комплексу при швидкісних перевезеннях $\epsilon$ повний розклад руху пасажирських швидкісних поїздів:

- графік курсування пасажирських швидкісних поїздів за датами;

- оперативна таблиця змін розкладу руху пасажирських швидкісних поїздів, надана ГІОЦ;

- масив пасажирських швидкісних поїздів залізниць.
Вихідною інформацією АСК пасажирського комплексу при швидкісних перевезеннях $є$ повний відкоригований розклад руху пасажирських та приміських поїздів:

- графік курсування пасажирських поїздів за датами;

- оперативна таблиця змін розкладу руху пасажирських і приміських поїздів, надана ГІОЦ;

- масив пасажирських поїздів залізниць.

Інформаційну технологію АCK пасажирського комплексу при швидкісних перевезеннях можна побудувати на функціональній основі 3 метою чіткого i своєчасного та якісного обслуговування пасажирів. При цьому виділяються основні функції 3 обслуговування пасажирів: квитково-касова; довідково-інформаційна; сервісна; побутова, а також господарська діяльність для підтримки в належному стані пасажирської технічної станції, будівель та устаткування вокзалу.

Довідково-інформаційні послуги $\epsilon$ найважливішими із складових частин організації обслуговування пасажирів, тому що дають змогу пасажиру одержати повну інформацію про перевезення: розклад руху пасажирських поїздів, періодичність їх курсування, маршрути прямування, умови проїзду, порядок придбання квитка, послуги пасажирського сервісу.

Довідкова інформація на вокзалах класифікується за змістом таким чином: про відправлення поїзда; про прибуття поїзда; про проїзд у приміському сполученні; питання про вартість проїзду і доплату; про час перебування поїзда в дорозі; довідка про маршрут прямування пасажирських поїздів; відомості про наявність місць у поїздах; про запізнення поїздів та ін.

Для підвищення обслуговування пасажирів важливе значення має етика: сукупність принципів та норм поведінки персоналу вокзалу. 
Коли пасажир входить у вокзал або виходить на залізничну платформу, то він має почувати себе комфортно. Допомагають у всьому цьому табло та уніфіковані за світовими стандартами покажчики.

На вокзалі спілкування 3 пасажиром починається не тільки тоді, коли він звертається до працівників вокзалу через постійну та змінну інформацію: покажчики, візуальна та інформація по радіо дають пасажирам відповіді, які виникають у пасажирів тільки в думці, дуже важливо, щоб необхідна інформація була видима, зрозуміла, своєчасна, яскрава або промовлена голосно i чітко та надана своєчасно.

Комфортні умови на вокзалі - це можливість пасажиру не звертатись до адміністраторів.

В умовах створення комплексу автоматизованих робочих місць персоналу різних рівнів керування пасажирського комплексу розширюються можливості ділового спілкування про призначення, відміну, зміну составності, рух швидкісних, пасажирських та приміських поїздів.

На базі АРМ спеціаліста пасажирської служби залізниці передається наказ про призначення, відміну, зміну состава, періодичність прямування пасажирських та приміських поїздів. Ця інформація постійно фіксується в системі «Експрес» і за допомогою комп'ютерної інформаційної мережі передається на АРМ станції і довідкового бюро вокзалу, доводиться до причетних виконавців.

Щодобово виконується перевірка наявності пасажирських поїздів, ці дані АРМ спеціаліста пасажирської служби передає на відповідні АРМ диспетчерського персоналу. При відсутності АРМ передача даних передбачається по телефону.

Найбільш сучасною $є$ інформація про виконання руху швидкісних, пасажирських поїздів на напрямках. $\mathrm{y}$ діючий інформаційній автоматизованій системі оперативного управління перевезеннями передбачена підготовка та передача до ІОЦ залізниці повідомлення 206 з призначених станцій передачі даних про пасажирські поїзди.

3 ІОЦ залізниці ці дані потрапляють на АРМ диспетчерського центру керування, а звідти на АРМ станції і довідкового бюро вокзалу. Таким чином зменшується тривалість надходження інформації до працівників про фактичний рух швидкісних, пасажирських поїздів порівняно з графіком руху. Інформація про поїзд має відображати код пункту передачі, номер поїзда, призначення поїзда, дату, час прямування за графіком та фактично.

При запізненні швидкісного пасажирського поїзда станційний диспетчер з черговим по станції приймають рішення про необхідність зміни колії прибуття, про що сповіщають 3 АРМ станційного диспетчера на АРМ довідкового бюро. На базі даної інформації сповіщаються причетні виконавці і пасажири [4].

Оперативне планування роботи пасажирського комплексу здійснюється на добу, зміну і 4-6 годинними періодами упродовж зміни. Підставою для змінного і поточного планування $\epsilon$ інформація про підхід поїздів, вагонів, локомотивів i розрахунок їх наявності, що допускається, на станції до початку планованого періоду. Схема отримання інформації та планування роботи пасажирського комплексу, на прикладі пасажирської станції Харків-Пас., наведена на рис. 3.

Умови оперативного планування роботи пасажирського комплексу:

- оперативне планування поїзної i маневрової роботи (на добу і зміну);

- ефективне використання технічних засобів, дотримання заходів щодо забезпечення безпеки руху, маневрової роботи і охорони праці працівників зміни;

- обробка системних документів в інформаційній технології АСК ПП УЗ-Є; 
- формування поїздів відповідно до встановленого плану формування поїздів і встановлених норм;

• контроль обліку і звітності роботи станції за основними показниками;

- впровадження нової техніки і технології, направлених на ефективне використання технічних засобів;

- оперативний контроль за використанням і вдосконаленням технічних засобів;

- оперативне керівництво обробкою поїздів і составів у парках станції;

- оперативне керівництво маневровою роботою, з прибирання і подавання составів швидкісних пасажирських поїздів і вагонів до ПТС;

- виконання змінного плану 3 приймання, відправлення, пропускання i технічної обробки поїздів;

- виконання технологічних норм 3 обробки поїздів і вагонів, максимальне поєднання технологічних операцій розформовування, формування і технічної обробки составів у парках станції;

- організація роботи станційного технологічного центру обробки інформації і перевізних документів.

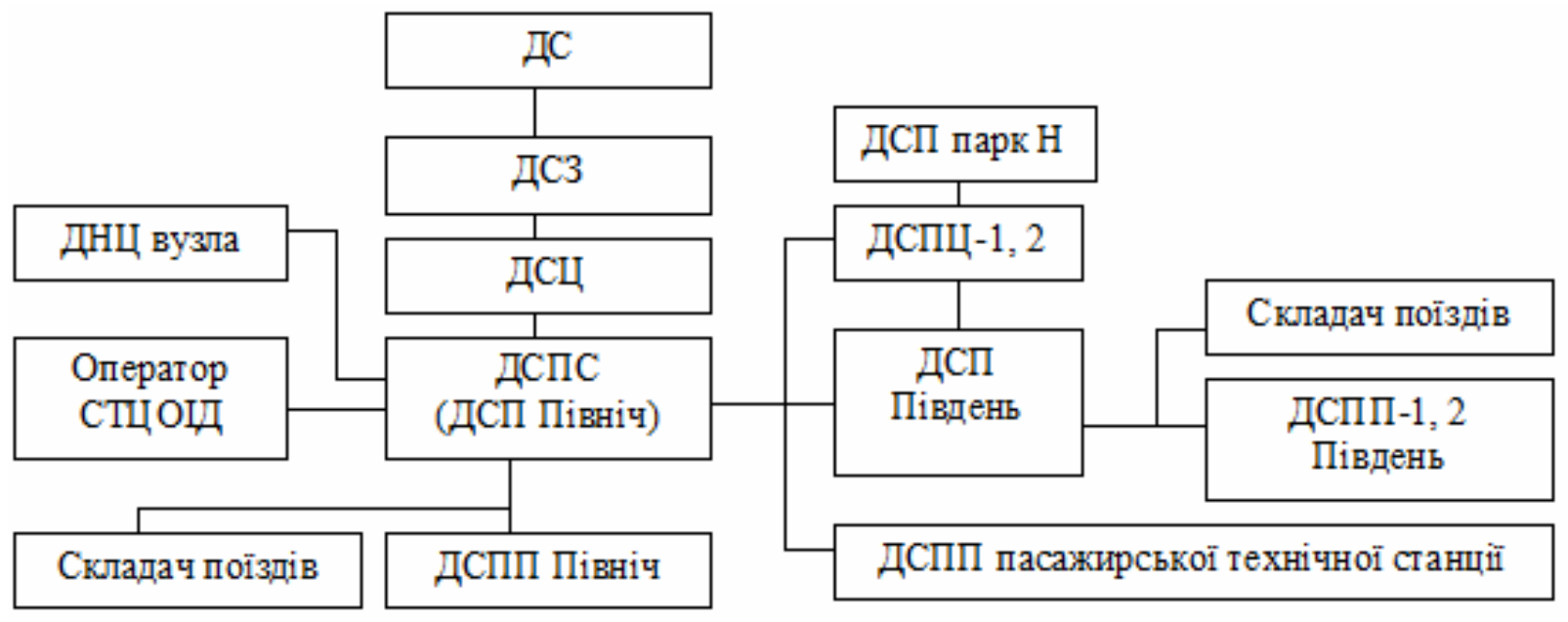

Рис. 3. Схема отримання інформації та планування роботи пасажирського комплексу

Модель тривалості відправлення на напрямок пасажирського швидкісного поїзда власності УЗШК або іншої операторської пасажирської компанії визначають «зворотним» розрахунком часу, виходячи 3 підсумку часу руху на перегонах та часу розгону-уповільнення на проміжних станціях за формулою:

$$
F\left(T_{n c_{i}}\right)=f\left[\frac{L_{i}}{\mu_{1} \cdot v_{x_{i}}}+\left(K_{n c} \cdot \mu_{2}+1\right)\left(t_{c m}^{n c}+t_{p}^{n c}+t_{y}^{n c}\right)\right] \text {, }
$$

де $L_{i}-$ довжина напрямку $i$ обертання пасажирського швидкісного поїзда, км; $K_{n c}$ - кількість станцій зі стоянками пасажирських швидкісних поїздів; $t_{c m}^{n c}, t_{p}^{n c}, t_{y}^{n c}-$ тривалість стоянок, розгону, уповільнення пасажирських швидкісних поїздів; 
$\mu_{1}$ - коефіцієнт, що враховує підвищення швидкості пасажирських швидкісних поїздів до звичайних пасажирських поїздів;

$\mu_{2}$ - коефіцієнт, що враховує скорочення кількості стоянок пасажирських швидкісних поїздів.
Модель обертання пасажирського швидкісного поїзда власності УЗШК або іншої операторської пасажирської компанії визначаємо за формулою:

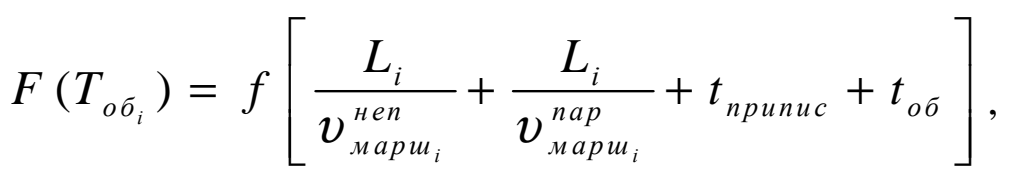

де $v_{\text {мари }}^{\text {нen }}, v_{\text {мари }}^{\text {nар }}$ - маршрутна швидкість, відповідно: в непарному i парному напрямках, км/год;

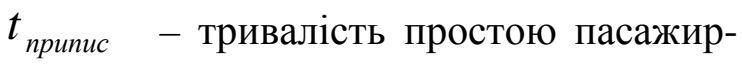
ського швидкісного поїзда на станції приписки, год;

$t_{\text {об }}$ - тривалість простою пасажирського швидкісного поїзда на станції обертання, год.

Модель потрібної кількості составів пасажирського швидкісного поїзда власності УЗШК або іншої операторської пасажирської компанії визначаємо за формулою:

$$
F\left(N_{i}\right)=f\left(\frac{T_{o \sigma_{i}}}{24}\right)
$$

де $T_{\text {об }}$ - обертання пасажирського швидкісного поїзда, год.

$N_{i}$ - потрібна кількість составів пасажирського швидкісного поїзда.

В автоматизованих системах керування пасажирського комплексу штучні нейронні мережі (ШНМ) можуть застосовуватися у вигляді: нейроконтролерів; нейроемуляторів, що імітують динамічне поводження об'єкта керування.
Синтез нейроконтролера роботи пасажирського комплексу при швидкісних пасажирських перевезеннях, на прикладі станції Харків-Пас. в умовах розвитку інформатизації можна виконати на базі тришарової прямонаправленої мережі [11]. Як об'єкт керування можна вибрати інерційну коливальну ланку другого порядку з передатною функцією виду

$$
W=\frac{k}{T^{2} s^{2}+2 T \varsigma S+1} .
$$

Мета керування - придушення коливань обсягів швидкісних пасажирських перевезень при роботі пасажирського комплексу при східчастому вхідному впливі (значення постійних коефіцієнтів $k=1 ; \quad T=0,5 ; \quad \varsigma=0,1$ підібрані так, щоб коливальні властивості в об'єкта були виражені досить чітко).

Структура нейроконтролера: три ретранслюючі вузли у вхідному шарі, чотири схованих вузли із сигмоїдальними активаційними функціями та один вихідний. На вхідні нейрони подається різниця між вхідним впливом $u_{r}$ і виходом об'єкта $x_{1}$, їі інтеграл і похідна, а на виході мережі формується керуючий вплив $u$ (рис. 4). 


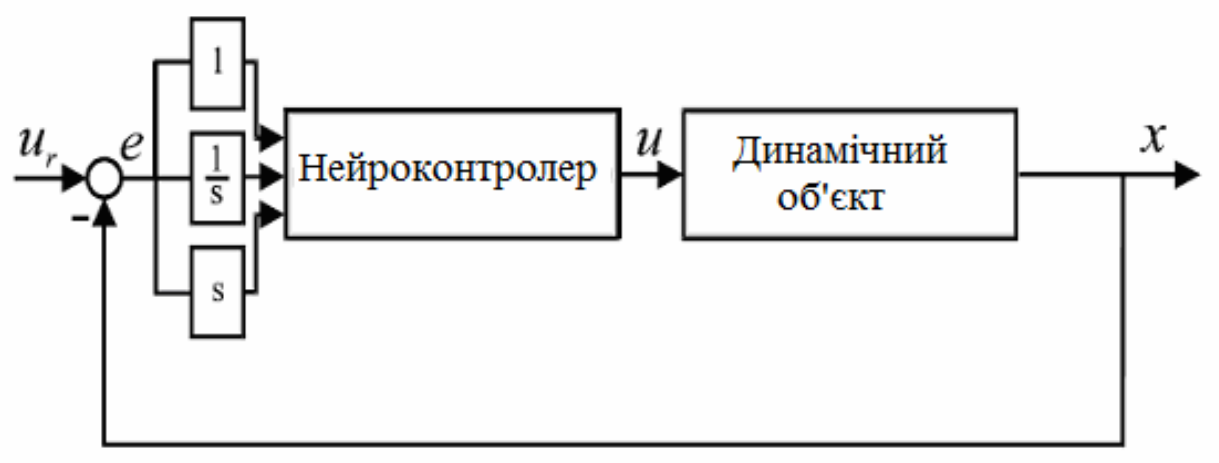

Рис. 4. Робота з нейроконтролером, що апроксимує коефіцієнти пропорційно-інтегродиференційного (ПІД)-регулятора

Для тренування мережі використовують генетичні алгоритми (ГА). Алгоритм зворотного поширення помилки вимагає інформації про помилку на ефекторному шарі ШНМ. Для одержання такої інформації в схемі навчання необхідно передбачити звернений нейроемулятор об'єкта, роль якого зводиться до перетворення помилки на виході об' єкта у вихідний сигнал на виході нейроконтролера, що істотно ускладнює процедуру тренування.

Генетичний же алгоритм набудовує параметри нейроконтролера не помилково в керуванні $u$, а помилково на виході об'єкта, порівнюючи його 3 виходом еталонної моделі. Остання втілює в собі подання про бажане поводження об'єкта, тобто відіграє приблизно ту саму роль, що і бібліотека тренувальних шаблонів у процедурі тренування (рис. 5).

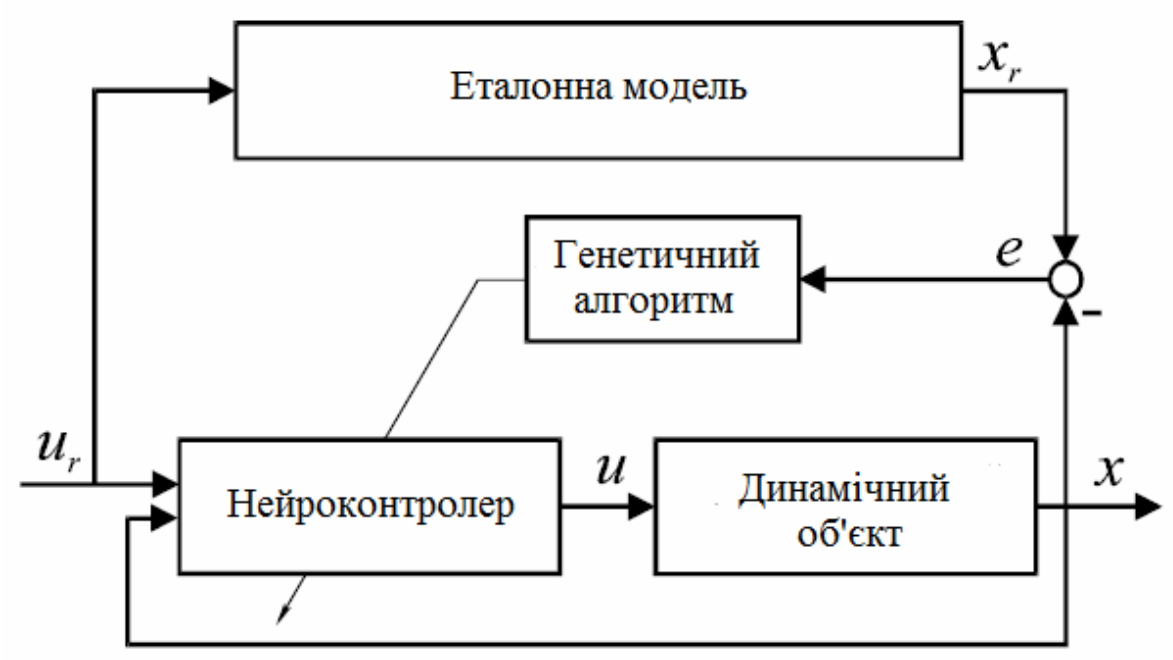

Рис. 5. Застосування ГА для настроювання параметрів нейроконтролера

Після декодування хромосом у вектори змінних оцінювалась здатність кожного варіанта мережі слідувати еталонній моделі. Перевірка здійснюється шляхом послідовної подачі на керуючий вхід нейроконтролера одиничного 
позитивного, нульового та одиничного негативного вхідного впливу і обчислення середньоквадратичної помилки вихідної координати об'єкта. Попередньо передатна функція об'єкта керування перетворюється в систему звичайних диференціальних рівнянь у формі Коші:

$$
\left\{\begin{array}{l}
\&=x_{2} ; \\
\&=\frac{-2 T \varsigma x_{2}-x_{1}+k U}{\sqrt{T}} .
\end{array}\right.
$$

Функціональні цілі при цьому будуть, порівняно 3 типовою технологією, поширені і торкатися, порівняно з іншими роботами, енергетичних витрат на не передбачуваних маневрових пересуваннях.

\section{Висновки 3 дослідження і перспек-} тиви, подальший розвиток у даному напрямку. Виникає можливість проаналізувати кількість, черговість застосування i зміст вищенаведених складових, узагальнити західний досвід у вигляді уніфікованого алгоритму, загалом зупинитися на задоволенні практичних потреб залізничного транспорту.
Інформаційну технологію АCK пасажирського комплексу при швидкісних перевезеннях можна побудувати на функціональній основі 3 метою чіткого i своєчасного та якісного обслуговування пасажирів. При цьому виділяються основні функції 3 обслуговування пасажирів: квитково-касова; довідково-інформаційна; сервісна; побутова, а також господарська діяльність для підтримки в належному стані пасажирської технічної станції, будівель та устаткування вокзалу.

Робота пасажирської станції та пасажирської технічної станції потребує розробки Єдиного технологічного процесу роботи пасажирського комплексу.

Проблемні питання, що виникають при взаємодії пасажирської станції, пасажирської технічної станції, УЗШК та інших операторських компаній, потребують посади маневрового диспетчера-розпорядника або ДСПП пасажирської технічної станції.

Синтез нейроконтролера роботи пасажирського комплексу при пасажирських швидкісних перевезеннях в умовах розвитку інформатизації можна виконати на базі тришарової прямонаправленої мережі.

\section{Список використаних джерел}

1. Концепція Державної цільової програми впровадження на залізницях швидкісного руху пасажирських поїздів на 2005-2015 роки [Електронний ресурс]: схвалена розпорядженням Кабінету Міністрів України від 31 грудня 2004 р. № 979-р. - Режим доступу: www/URL: http://ukraine.uapravo.net/data/base23/ukr23446.htm. - Загол. з екрана.

2. Державна цільова програма реформування залізничного транспорту на 2010-2019 роки [Електронний ресурс]: в ред. постанови Кабінету Міністрів України від 26 жовтня 2011 p. № 1106. - Режим доступу: www/URL: http://zakon4.rada.gov.ua/laws/show/1106-2011-п. - Загол. $з$ екрана.

3. Данько, M. I. Управління експлуатаційною роботою і якістю перевезень на залізничному транспорті [Текст]: навч. посібник / М.І. Данько, Т.В. Бутько, О.В. Березань [та ін.]. - Харків: УкрДАЗТ, 2008. - 174 с.

4. Данько, Н. И. Разработка организационно-технологической модели управления парком грузовых вагонов разной формы собственности [Текст] / Н.И. Данько, Д.В. Ломотько, В.В. Кулешов // Инновационный транспорт: научно-публицистическое издание. - 2012. - №4(5). - С. 8-13. 
5. Калашнікова, Т. Ю. Удосконалення інформаційно-керуючої системи залізниць в умовах інтероперабельності [Текст] / Т. Ю. Калашнікова, С. М. Кушкін, Є. Д. Куценко // Зб. наук. праць Укр. держ. акад. залізнич. трансп. - Харків: УкрДАЗТ, 2014. - Вип. 146 - С. 6165.

6. Кулешов, В. В. Удосконалення інформаційної технології роботи з вагонами різних форм власності з метою оптимізації пропускної спроможності залізничних транспортних систем [Текст] / В.В. Кулешов // Зб. наук. праць Укр. держ. акад. залізнич. трансп. - Харків: УкрДАЗТ, 2011. - Вип. 124. - С. 83-90.

7. Кулешов, В.В. Формування Єдиної технології процесу перевезень операторів рухомого складу на інфраструктурі залізниць [Текст] / В.В. Кулешов // Вагонный парк. 2014. - № 7(88). - С. 4-7.

8. Лючков, Д. С. Анализ внедрения скоростного железнодорожного движения в Украине [Текст] / Д. С. Лючков, Ю. Л. Бердник // Вагонный парк. - 2010. - № 12. - С. 28-30.

9. Самсонкін, В. М. Основи реорганізації пасажирського комплексу залізничного транспорту [Текст] / В. М. Самсонкін, О. М. Гудков // Вісник економіки транспорту i промисловості. - 2009. - № 25. - С. 78-81.

10. Сухорукова, Т. Г. Перспективи розвитку пасажирського комплексу Південної залізниці 3 урахуванням досвіду роботи залізничних компаній світу [Текст] / Т. Г. Сухорукова, Л. В. Гуляєва // Вісник економіки транспорту і промисловості. - 2010. - № 32. - C. 45-49.

11. Розсоха, О.В. Моделювання пасажирських поїздопотоків високошвидкісних залізничних магістралей [Текст] / О. В. Розсоха, В. М. Солонець // Зб. наук. праць Укр. держ. акад. залізнич. трансп. - Харків: УкрДАЗТ, 2015. - Вип. 154. - С. 5-13.

12. Ходаківський, О. М. Дослідження функціонування пасажирської станції на основі теорії систем [Текст] / О. М. Ходаківський, О. М. Огар, Т. Ю. Калашнікова, Ю. В. Хоменко // 3б. наук. праць. - Харків: НТУ «ХПІ», 2009. - Вип. 8. - С. 69-73.

13. Генетические алгоритмы, искусственные нейронные сети и проблемы виртуальной реальности [Текст] / Г. К. Вороновский, К. В. Махотило, С. Н. Петрашев, С. А. Сергеев. Харьков: ОСНОВА, 1997. - 112 с.

14. Newman, M. The structure and function of complex networks. SIAM Review, 2003. -45. $-167-256$

15. Yung-Cheng Lai, Dow-Chung Fan, Kwei-Long Huang Optimizing rolling stock assignment and maintenance plan for passenger railway operations // Computers \& Industrial Engineering. Volume 85, July 2015. - 284-295.

16. Jørgen T. Haahr, Joris C. Wagenaar, Lucas P. Veelenturf, Leo G. Kroon A comparison of two exact methods for passenger railway rolling stock (re)scheduling// Transportation Research Part E: Logistics and Transportation Review. Volume 91, July 2016. - 15-32.

Рецензент д-р техн. наук, професор Є.С. Альошинський

Кулешов Валерій Вячеславович, канд. техн. наук, доцент кафедри залізничних станцій та вузлів Українського державного університету залізничного транспорту. Тел.: (057) 730-10-42.

E-mail: valerijkuleshov2015@gmail.com.

Чеботарьов Денис Миколайович, слухач Навчально-наукового інституту перепідготовки та підвищення кваліфікації кадрів Українського державного університету залізничного транспорту. Тел.: (057) 730-10-42.

Kuleshov Valeriy Vaycheslavovich, PhD. Sc., assistant professor of railway stations and junctions Ukrainian State University of Railway Transport. Tel.: (057) 730-10-42. E-mail: valerijkuleshov2015@gmail.com.

Chebotarev Denys Mykolaevich, listener Training and Research Institute of retraining and advanced training of Ukrainian State University of Railway Transport. Tel.: (057) 730-10-42.

Стаття прийнята 21.06.2016 p. 